\title{
Serum Copeptin as the Predictor for Acute Heart Failure Complication of Acute Myocardial Infarction in Patients with ST-Segment Elevation
}

\author{
Ardi Putranto, JB. Suparyatmo, Dian Ariningrum \\ Department of Clinical Pathology, Faculty of Medicine, Sebelas Maret University/Dr. Moewardi General Hospital, Surakarta, Indonesia. E- \\ mail:dokter_ardi85@ymail.com
}

\begin{abstract}
Acute Myocardial Infarction (AMI) is necrotic cardiac muscle cells due to unstable ischemic syndrome. Therapy monitoring is needed because various complications may occur (Heart Failure/HF). ST-Segment Elevation Myocardial Infarction (STEMI) can develop to Acute Heart Failure (AHF) due to myocardial dysfunction, transmural heart disease, pathological cardiac remodeling. Copeptin is an antidiuretic hormone which increases in the cardiac event. It can be used as a predictor of a further cardiac event. This study aimed to determine the role of serum copeptin level as a predictor of AHF complication in STEMI patients. A prospective cohort study was performed in 85 adult STEMI patients admitted to the Clinical Pathology Installation of Dr. Moewardi Hospital, Surakarta. Data with normal and abnormal distribution were presented in mean \pm Standard Deviation (SD) and median (min-max), respectively. Statistical analysis was performed using Kolmogorov-Smirnov, bivariate, and multivariate analysis for Relative Risk (RR) with Confidence Interval (CI) of 95\% and $p<0.05$ was considered significant. The copeptin cut-off point was determined using the ROC curve. Bivariate and multivariate analysis showed a higher copeptin level in STEMI patients with AHF compared to that of non-AHF (RR=5.172, CI 95\% 1.795-14.902, $p=0.002$ and RR=1.889, CI 95\% 1.156-3.086, $\mathrm{p}=0.001$; respectively). The STEMI patients with an elevated level of copeptin showed an increased risk of AHF (STEMI with elevated copeptin level vs. STEMI with normal copeptin level; $28.74 \%$ vs. $88.91 \%$ ). Copeptin level is significantly related to AHF complication in STEMI patient, the higher level of copeptin led to the higher the risk of AHF.
\end{abstract}

Keyword: ST-segment elevation myocardial infarction, copeptin, acute heart failure

\section{INTRODUCTION}

Acute Myocardial Infarction (AMI), both AMI with STEMI and non-STEMI (NSTEMI) are emergency cardiac events which have a fairly high morbidity and mortality. ${ }^{1}$ Acute myocardial infarction with elevated ST-segment is acute angina pectoris with persistent elevation of ST-segment in two adjacent leads. ${ }^{1,2}$ It also one of the health problems in Indonesia. The survey released by the Indonesian Ministry of Health (Kemenkes RI) showed that Coronary Heart Disease (CHD) ranks third as the leading cause of death after stroke and hypertension. ${ }^{3.4}$ According to Basic Health Research in 2007, 5.1\% of all deaths were caused by ischemic heart disease, and $4.6 \%$ of deaths were caused by heart disease. ${ }^{5}$

Heart Failure (HF) is a group of complex symptoms, which include shortness of breath at rest or during activities with/without fatigue, signs of fluid retention (pulmonary congestion or ankle swelling), and the presence of objective finding of impaired structure or function of resting heart. ${ }^{6}$ Diagnosis of Acute Heart Failure (AHF) is made when a patient exhibits acute signs and symptoms of $\mathrm{HF}$, usually accompanied by decompensated cardiomyopathy. ${ }^{2}$

Acute heart failure complications can occur in STEMI. It generally occurs in the acute and subacute phase. It is caused by myocardial dysfunction, microvascular obstruction of the anterior wall, and the consequences of sustained arrhythmias or mechanical complications. ${ }^{1,7}$ Non-invasive cardiac markers with good sensitivity and specificity are needed as predictors of STEMI patients, especially for monitoring the complications of AHF. ${ }^{2}$

Some cardiac markers that function for prognostic evaluations include B-type Natriuretic Peptide (BNP) and $\mathrm{N}$-terminal BNP prohormone (NT-proBNP) which are considered very good to assess the prognosis of AMI. ${ }^{8}$ But these markers still have some disadvantage as they are too dependent on age, kidney function, and the variation of BNP plasma, which shows the remarkably big difference over time. ${ }^{9}$

Study on prognostic markers of heart disease continues to develop until now, one of them is copeptin. ${ }^{10}$ Copeptin compounds consist of the C-end peptide of provasopressin, and Arginine Vasopresin 
(AVP) precursor, a hypothalamic antidiuretic hormone. ${ }^{7}$ Its synthesis follows Arginine vasopresin in neurohypophysis or posterior pituitary and is triggered by decreased cardiac output, increased state of osmolality, and physiological stress. ${ }^{11,12}$ Arginine vasopresin only lasts 5-15 minutes in ambient temperature, it has a small molecular size, low platelet affinity (<90\%), difficult storage and it takes much time of test (12-24 hours). ${ }^{7,10}$ Contrastingly, copeptin has long-endurance (7-14 days) in room temperature, high platelet affinity (> $90 \%)$, large molecular size, easy storage and it requires less time of test (1-5.5 hours). ${ }^{11,12}$ Copeptin can be used as a diagnostic and prognostic agent, especially in patients with cardiac abnormalities. ${ }^{13}$

Studies on copeptin level as a predictor of AHF events in AMI patients have been carried but still few are performed in Indonesia. Therefore, we performed this study to analyze the copeptin level as a predictor of AHF complication in STEMI patients.

\section{METHODS}

This observational analytical study with a prospective cohort approach was performed on newly diagnosed STEMI patients who were admitted to the RSDM (Rumah Sakit Doktor Moewardi) Emergency Department (ED) and treated at RSDM Surakarta between October and December 2018.

All adult patients with newly diagnosed STEMI based on PERKI standard (angina pectoris with ECG showing ST-segment elevation and CTnI increase at $\mathrm{T} 0 \geq 100 \mathrm{ng} / \mathrm{L}$ or $\mathrm{T} 2$ hours $\geq 10 \mathrm{ng} / \mathrm{L}$ and creatinine kinase-myocardial binding - CKMB-mass of $4.3 \mathrm{ng} / \mathrm{L}$ ) and signed informed consent were included in our study. The exclusion criteria were patients with a previous history of heart failure, previous AMI or the other heart failure disease, impaired kidney function, liver function disorder, and acute infection (leukocyte count above the normal range). ${ }^{14}$ This study involved 85 patients using the Killip score criteria to determine AHF classification as follows: class I: no symptoms, class II: S3 and basal rales, class III: class II with acute pulmonary edema, class IV: class III with cardiogenic shock. Laboratory parameters for this study were high sensitive troponin I measured with mini vidas based on the Enzyme-Linked Fluorescent Assay (ELFA) method, sodium (hyponatremia) measured with Ilyte based on ion-selective electrode method, and copeptin measured with Rayto RT 2100 C based on enzyme-linked immunosorbent assay method. Elabscience human CPP (copeptin) Elisa kit was used for copeptin levels measurement in this study.

The accuration and the precision of laboratory equipment were tested, to ensure the quality of the test results. The characteristics of the study subjects were presented in mean and Standard Deviation (SD). Bivariate and multivariate analyses were performed. Statistical analysis was processed by using a computer program, with a $p$-value of $<0.05$ and $95 \%$ CI was considered significant. This study was approved by the Ethics Committee of Dr. Moewardi Hospital Surakarta (14778/UN27.06.7.10/PP/2018).

\section{RESULTS AND DISCUSSION}

The baseline characteristics of the subject's study and the characteristics of the research variables are shown in Table 1 and Table 2, respectively.

The subjects in this study had a median systolic and diastolic blood pressure of 110 and $70 \mathrm{mmHg}$,

Table 1. Baseline characteristics of the study subjects

\begin{tabular}{|c|c|c|}
\hline Variable & n (\%) & Mean $\pm S D / M e d i a n(\min -\max )$ \\
\hline Systolic $(\mathrm{mm} / \mathrm{Hg})^{\star \star}$ & & $110(80-164)$ \\
\hline Diastolic $(\mathrm{mm} / \mathrm{Hg})^{\star \star}$ & & $70(40-102)$ \\
\hline Respiratory rate $(/ \text { minute })^{\star \star}$ & & $25(16-32)$ \\
\hline $\mathrm{HR}(/ \text { minute })^{*}$ & & $90.88 \pm 14.88$ \\
\hline Killip: I & $24(28.2)$ & \\
\hline II & $48(56.5)$ & \\
\hline III & $10(11.8)$ & \\
\hline IV & $3(3.5)$ & \\
\hline Smoking: Yes & $34(40)$ & \\
\hline No & $51(60)$ & \\
\hline Outcome: Life & $81(95.29)$ & \\
\hline Death & $4(4.71)$ & \\
\hline
\end{tabular}

${ }^{*}=$ normal distribution; ${ }^{* *}=$ abnormal distribution; $\mathrm{mmHg}=$ milimetre of Mercury; HR = Heart Rate; $\mathrm{SD}=$ Standard Deviation; $\mathrm{n}=$ sample 
Table 2. Variable characteristics

\begin{tabular}{|c|c|c|}
\hline Variable & n (\%) & Mean $\pm S D / M e d i a n(\min -\max )$ \\
\hline Gender: Male & $60(70.6)$ & \\
\hline Female & $25(29.4)$ & \\
\hline Age (years)*: < 60 & $42(49.4)$ & $60.91 \pm 14.02$ \\
\hline$\geq 60$ & $43(50.6)$ & \\
\hline DM: Yes & $31(36.5)$ & \\
\hline No & $54(63.5)$ & \\
\hline HT: Yes & $53(62.4)$ & \\
\hline No & $32(37.6)$ & \\
\hline AHF: Yes & $61(71.8)$ & \\
\hline No & $24(28.2)$ & \\
\hline hs-trop I (ng/L)**: $\quad<56.3$ & $30(35.3)$ & $346(41-4000)$ \\
\hline$\geq 56.3$ & $55(64.7)$ & \\
\hline Sodium (mmol/L)**: > 130 & $81(95.3)$ & $136(126-146)$ \\
\hline$\leq 130$ & $4(4.7)$ & \\
\hline Copeptin (pg/mL)*: < 207.5 & $27(31.8)$ & $311.34 \pm 235.26$ \\
\hline$\geq 207.5$ & $58(68.2)$ & \\
\hline
\end{tabular}

* = normal distribution; ${ }^{* *}=$ abnormal distribution; $\mathrm{DM}=$ Diabetes Melitus; $\mathrm{HT}=$ hypertension;

$\mathrm{AHF}=$ Acute Heart Failure; $\mathrm{pg} / \mathrm{mL}=$ picogram per mililitre; $\mathrm{ng} / \mathrm{L}=$ nanogram per litre;

$\mathrm{mmol} / \mathrm{L}=$ milimole per litre; $\mathrm{n}=$ sample; $\mathrm{SD}=$ Standard Deviation; $\min =$ minimum; $\max =$ maximum .

respectively. This study showed the median of respiratory rate of $25 /$ minute and the average of the Heart Rate (HR) of $90.88 \pm 14.88 /$ minute. Forty-eight subjects (56.5\%) in this study were classified in Killip II. This study population was dominated by patients without any history of smoking (51-60\% subjects). Eighty-one subjects (95.29\%) survived and 4 subjects (4.71\%) died when they were discharged from the hospital (Table 1).

There were 85 subjects in this study consisting of 60 males and 25 females. The average age of this study was $60.91 \pm 14.02$ years. There were 31 subjects with DM and 54 subjects without DM. Hypertension was observed in 53 subjects (62.4\%) and 32 subjects (37.6\%) without HT. The average copeptin level was $311.34 \pm 235.26 \mathrm{pg} / \mathrm{mL}$. The median for hs-troponin I and serum sodium levels (Table 2) was 346 (41-4000) $\mathrm{ng} / \mathrm{L}, 136$ (12-146) $\mathrm{mmol} / \mathrm{L}$, respectively.

The ROC curve showed the diagnostic performance of copeptin as AHF predictors (Figure 1). Based on the ROC and AUC curve, we obtained visual information and the number of predictions (AUC) of the copeptin level used to predict the occurrence of AHF. The selected cut-off point of copeptin was $\geq 207.5 \mathrm{pg} / \mathrm{mL}$ and that of AHF was $77.7 \%$ with $95 \%$ CI between 67.2 and $88.1 \%$ (Table 3).

This study showed that the levels of copeptin $\geq 207.5 \mathrm{pg} / \mathrm{mL}$, copeptin $<207.5 \mathrm{pg} / \mathrm{mL}$, hs-troponin I

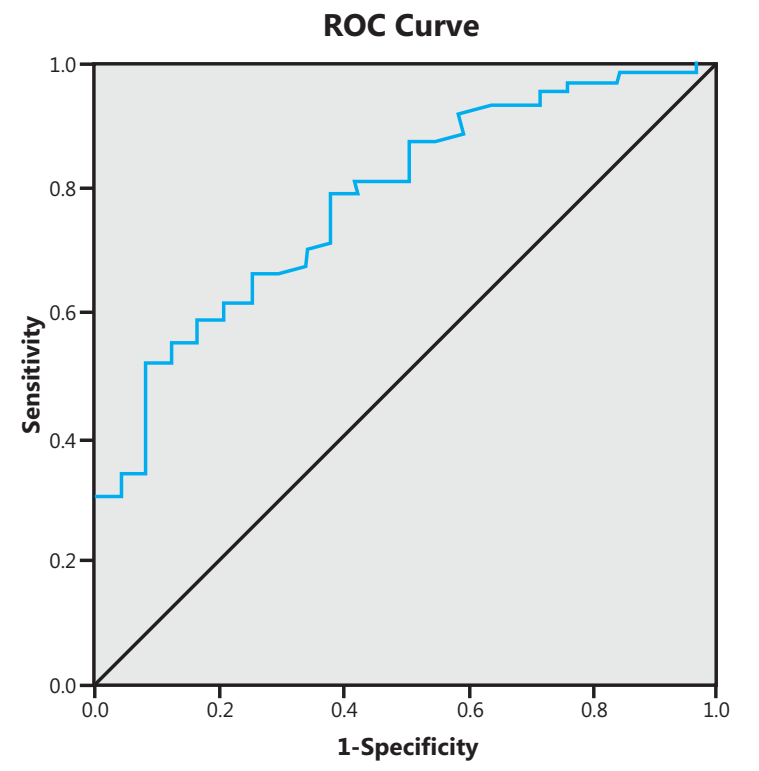

Figure 1. Copeptin ROC curve

$\geq 56.3 \mathrm{ng} / \mathrm{L}$, hs-troponin I $<56.3 \mathrm{ng} / \mathrm{L}$, sodium serum $\leq 130 \mathrm{mmol} / \mathrm{L}$ and sodium $>130 \mathrm{mmol}$ were found in 58 (68.2\%), 15 (31.8\%), 55 (64.7\%), 30 (35.3\%), 4 (4.7\%) and 81 (95.3\%) subjects, respectively.

The $2 \times 2$ test of HF complications with age, gender, history of HT, history of DM, copeptin, hs-troponin I and sodium serum levels that might affect the results found the value of RR (CI 95\%) for gender, age, history of DM, HT, hs-troponin I, sodium 
Table 3. Diagnostic performance of copeptin as the AHF predictor

\begin{tabular}{cccc}
\hline Copeptin (pg/mL) & $\begin{array}{c}\text { Sensitivity } \\
\text { (CI 95\%) }\end{array}$ & $\begin{array}{c}\text { Specificity } \\
\text { (CI 95\%) }\end{array}$ & $\begin{array}{c}\text { Accuracy } \\
\text { (CI 95\%) }\end{array}$ \\
\hline 200.000 & 80.3 & 54.2 & 64.3 \\
204.000 & 78.7 & 58.3 & 63.8 \\
207.500 & 78.7 & 62.5 & 66.8 \\
209.000 & 77.0 & 62.5 & 66.4 \\
213.000 & 75.4 & 62.5 & 65.9 \\
\hline
\end{tabular}

$\mathrm{pg} / \mathrm{mL}=$ picogram per mililiter; $\mathrm{CI}=$ Confidence Interval

Table 4. Bivariate analysis among variables as the AHF predictor

\begin{tabular}{|c|c|c|c|c|c|c|c|}
\hline \multirow{2}{*}{ Variable (unit) } & & \multicolumn{4}{|c|}{ AHF Complication } & \multirow{2}{*}{ RR (CI 95\%) } & \multirow{2}{*}{$\mathbf{p}$} \\
\hline & & Yes & $\%$ & No & $\%$ & & \\
\hline \multirow[t]{2}{*}{ Gender: } & Male & 44 & 51.8 & 16 & 18.8 & $1.082(0.783-1.495)$ & 0.621 \\
\hline & Female & 17 & 20 & 8 & 9.4 & & \\
\hline \multirow[t]{2}{*}{ Age (years): } & $\geq 60$ & 31 & 36.5 & 12 & 14.1 & $1.016(0.635-1.626)$ & 0.946 \\
\hline & $<60$ & 30 & 35.3 & 12 & 14.1 & & \\
\hline \multirow[t]{2}{*}{ DM: } & Yes & 23 & 27.1 & 8 & 9.4 & $1.131(0.590-2.170)$ & 0.705 \\
\hline & No & 38 & 44.7 & 16 & 18.8 & & \\
\hline \multirow[t]{2}{*}{ HT: } & Yes & 41 & 48.3 & 12 & 14.1 & $1.344(0.869-2.081)$ & 0.143 \\
\hline & No & 20 & 23.5 & 12 & 14.1 & & \\
\hline \multirow[t]{2}{*}{ hs-Trop I (ng/L): } & $\geq 56.3$ & 43 & 50.6 & 12 & 14.1 & $1.694(0.971-2.958)$ & 0.077 \\
\hline & $<56.3$ & 18 & 21.2 & 12 & 14.1 & & \\
\hline \multirow[t]{2}{*}{ Sodium (mmol/L): } & $>130$ & 59 & 69.3 & 22 & 25.9 & $1.055(0.927-1.201)$ & 0.325 \\
\hline & $\leq 130$ & 2 & 2.4 & 2 & 2.4 & & \\
\hline \multirow[t]{2}{*}{ Copeptin (pg/mL): } & $\geq 207.5$ & 48 & 56.5 & 10 & 11.8 & $1.889(1.156-3.086)$ & 0.001 \\
\hline & $<207.5$ & 13 & 15.3 & 14 & 16.4 & & \\
\hline Total & & 61 & 71.8 & 24 & 28.2 & & \\
\hline
\end{tabular}

$\mathrm{AHF}=$ Acute Heart Failure; $\mathrm{DM}=$ Diabetes Melitus; $\mathrm{HT}=$ hypertension; $\mathrm{pg} / \mathrm{mL}=$ picogram per mililiter; $\mathrm{ng} / \mathrm{L}=$ nanogram per liter; $\mathrm{mmol} / \mathrm{L}=$ milimole per liter; $\mathrm{RR}=$ Relative Risk; trop = troponin; $\mathrm{CI}=$ Confidence Interval; $\mathrm{p}<0.05$ is significant.

Table 5. Multivariate analysis among variables as the AHF predictor

\begin{tabular}{ccccc}
\hline & \multirow{2}{*}{$\mathbf{R}$} & \multicolumn{2}{c}{ CI 95\% } & \multirow{2}{*}{$\mathbf{p}$} \\
\cline { 3 - 4 } & & Min & Max & \\
\hline Hypertension & 1.62 & 0.566 & 4.644 & 0.368 \\
hs-troponin I & 2.42 & 0.810 & 6.916 & 0.116 \\
Copeptin & 5.17 & 1.795 & 14.902 & 0.002 \\
Constant & 0.403 & & & 0.136 \\
\hline
\end{tabular}

$\mathrm{RR}=$ Relative Risk; $\mathrm{CI}=$ Confidence Interval; $\min =$ minimum; $\max =$ maximum

and copeptin levels were $1.082(0.783-1.495 ;$ $\mathrm{p}=0.621), \quad 1.016(0.635-1.626, \quad \mathrm{p}=0.946), 1.131$ (0.590-2.170, $p=0.705), 1.344 \quad(0.869-2.081$, $\mathrm{p}=0.143), \quad 1.694(0.971-2.958, \quad p=0.077), 1.055$ (0.927-1.201, $p=0.325)$, and 1.889 (1.156-3.086, $\mathrm{p}=0.001)$, respectively. In this study, a significant result of the copeptin level of $\geq 207.5 \mathrm{pg} / \mathrm{mL}$ found in STEMI patients who had 1.9 times of risk to be affected by AHF (Table 4).

Multivariate analysis was performed if the variables showed $p<0.25$ in bivariate analysis. ${ }^{14-16}$ In this study there were three variables with $\mathrm{p}<0.25$ (HT history, $p=0.143$; hs-troponin I, $p=0.077$; copeptin, $p=0.001)$; therefore, the multivariate analysis was performed on the three parameters (Table 5). The variables affecting the occurrence of AHF were HT history, hs-troponin level, and serum copeptin level. The strength of the relations could be seen from the $R R$ value, with the largest and the smallest relations strength were serum copeptin $(R R=5.17)$ and 
history of $\mathrm{HT}(\mathrm{RR}=1.62)$.

The multivariate formula is $\mathrm{y}=$ constant coefficient + coefficient (history of HT) + coefficient (hs-troponin I) + coefficient (copeptin). Hospitalized patients with STEMI without abnormalities such as a history of hypertension, increased levels of hs-troponin I and increased serum copeptin were $28.74 \%$ more likely to have AHF during hospitalization.

Hospitalized patients with STEMI and some abnormalities such as a history of hypertension, increased hs-troponin I levels and increased serum copeptin were $88.91 \%$ more likely to have AHF during hospitalization.

In this study, 61 and 24 patients showed AHF and no complications, respectively. The population of male patients with AHF complications was greater than female $(51.8 \%$ vs. $20 \%$, OR $=1.082,95 \% \mathrm{CI}$ $0.783-1.495)$. This finding was contradictory to the research of Cahill and Kharbanda, which reported that post-AMI-EST AHF patients were dominated by females (OR $=1.34,95 \%$ CI: 1.1-1.51) ${ }^{15}$ This is due to the incomparable average age of each gender in this study, which showed that females were dominated by $<60$ years of age (15 patients; 17.64\%), while males were dominated by age $\geq 60$ years ( 33 patients; $38.82 \%)$. In this study population, there were a higher number of male subjects with $D M$ and AHF (22 patients; $25.88 \%$ vs. 9 patients; $10.56 \%)$, HT and AHF (38 patients; $44.71 \%$ vs. 15 patients; $17.65 \%$ )

The average age of this study was $60.91 \pm 14.02$ years, similar to the study by Gho et al. suggesting that post-AMI-EST AHF patients were more common at the age above 60 years. ${ }^{16}$ These findings were also in accordance to research by Nunez et al., which showed an increase in HR (1.96; 95\% CI 1.52-2.54) for each additional age of ten years, there was a decrease in organ function and a decrease in the effectiveness of both intervention and medical therapy. ${ }^{17}$

The history of DM with AHF complications in this study was found in 23 subjects (27.1\%), which was a contrast to a study by Ammar, in which the patients with a history of DM were more affected by AHF than those without a history of DM. If the glycemic index is well controlled, the incidence of insulin resistance that can trigger AHF will decrease. ${ }^{18}$

The history of HT with AHF complications was found in 41 subjects (48.2\%). This finding was similar to the study by Carillo et al., which showed that a group of post-AMI hypertensive patients had a higher number of HF complications compared to the group without hypertension. ${ }^{19}$ This finding was also supported by research by Ali et al., which found $19.7 \%$ of patients with HF complications with a history of hypertension and $12.9 \%$ of patients with no HF complications in hospital care $(p<0.05){ }^{20}$ Left ventricular hypertrophy in HT patients associated with the enlarged size of cardiac myocytes, accompanied by an increase in the number of non-myocytes (fibroblasts), accumulation of collagen, and infiltration of monocytes and lymphocytes. Therefore, patients with a history of HT and $\mathrm{AMI}$ are very susceptible to $\mathrm{HF}$ complications. ${ }^{20}$

The levels of hs-troponin I was above the cut-off value $(56.3 \mathrm{ng} / \mathrm{L})$ with complications of $\mathrm{AHF}$ found in 43 subjects (50.6\%). This result was similar to the journal review by Feistrizer et al., which suggested hs-troponin as a good non-invasive parameter that detects complications after post-AMI. ${ }^{21}$ Cardiac troponin is a component of contractility of cardiomyocytes, which is gradually released into circulation as a response to myocardial injury. When HF complications occur, high levels of cardiac troponin are released into circulation. The cardiac troponin parameter is not only used for diagnostics but can also be used as a prognostic. Also, some studies use hs-troponin as a predictor of death in post-AMI patients. ${ }^{21}$

Decreased sodium levels with complications of AHF were found in two subjects (2.4\%), showing a contradictory result to study by $\mathrm{Ma}$, suggesting that hyponatremia was good as a predictor of post-AMI HF (cut-off: $\leq 130 \mathrm{mmol} / \mathrm{L}$ ), while sodium levels $>130$ $\mathrm{mmol} / \mathrm{L}$ with AHF complications were found in 59 subjects $(69.4 \%){ }^{22}$ Medical cardiovascular disease and $\mathrm{NaCl}$ type infusion during initial admission can affect serum sodium levels (normal or even higher).

Serum copeptin levels above the cut-off value $(207.5 \mathrm{pg} / \mathrm{mL})$ with complications of AHF in 61 subjects (65.9\%) in this study was in line with a study by O'Malley et al., which suggested that copeptin is a strong prognostic biomarker for post-NSTEMI HF with a cut-off $(12.70 \mathrm{pmol} / \mathrm{L}){ }^{23}$ The difference between this research and the research by O'Malley et al. are sample populations, a cut-off of copeptin, and copeptin units. Copeptin is a peptide released during hemodynamic stress without its direct relationship to atherothrombosis, causing this parameter more suitable for predictors of AHF and death than recurrent events from NSTEMI. ${ }^{23,24}$

This study demonstrated that serum copeptin could be used as an independent predictor of post-AMI-EST GK complication, whereas a history of $\mathrm{HT}$ and hs-troponin I could be used as additional predictors. Also, gender, age, history of DM, and 
sodium could not be used as predictors of post-STEMI AHF complications. However, there were a limited number of patients included from a single recruiting medical center (single-center study).

\section{CONCLUSION AND SUGGESTION}

This study showed a statistically significant relation between serum copeptin levels and the incidence of post-STEMI complications. Gender, age, history of DM, history of HT, levels of hs-troponin I, and hyponatremia showed no significant relation to the incidence of post-STEMI complications in ICVCU patients at Dr. Moewardi Hospital.

Further study was needed to evaluate the relations of serum copeptin levels to the incidence of post-STEMI AHF complications, by using more samples and additional diagnostic parameters such as infarct area found in Computerized Tomography $(\mathrm{CT})$, ejection fraction echocardiography, using APACHE-HF (acute physiology and chronic health evaluation heart failure) scoring and medical history.

\section{REFERENCES}

1. Anderson JL, Morrow DA. Acute myocardial infarction. The New England Journal of Medicine, 2017; 376: 2053-2064.

2. Juzar DA, Danny SS, Irmalita, Tobing DPL, Firdaus I, et al. Perhimpunan Dokter Spesialis Kardiovaskular Indonesia. Pedoman tata laksana sindrom koroner akut. Ed IV., Jakarta, Indonesian Heart Association, 2018; 4: 1-94.

3. Badan penelitian dan pengembangan kesehatan Kementerian Kesehatan Republik Indonesia. Riset kesehatan dasar 2013. Ed I., Jakarta, Badan Penelitian dan Pengembangan Kesehatan, 2013; 1-306.

4. Hastuti YE, Elfi EF, Pertiwi D. Hubungan kadar troponin $T$ dengan lama perawatan pasien infark miokard akut di RSUP Dr. M. Djamil Padang periode 01 Januari - 31 Desember 2013. Jurnal Kesehatan Andalas, 2013; 6(2): 423-428.

5. Badan penelitian dan pengembangan kesehatan Kementerian Kesehatan Republik Indonesia. Riset kesehatan dasar, laporan nasional 2007. Ed I., Jakarta, Badan penelitian dan pengembangan kesehatan Kementerian Kesehatan RI, 2007; 1-306.

6. Siswanto BB, Hersunarti N, Erwinanto, Barack R, Pratikto RS, et al. Perhimpunan Dokter Spesialis Kardiovaskular Indonesia. Pedoman tata laksana gagal jantung. Ed I. Jakarta, Indonesian Heart Association, 2015; 3: 1-56.

7. Balling L, Gustafsson F. Copeptin in heart failure. Advances in Clinical Chemistry, 2016; 73: 29-64.

8. Voors AA, Haehling SV, Anker SD, Hillege HL, Struck J, et al. C-terminal provasopressin (copeptin) is strong prognostic marker in patients with heart failure after an acute myocardial infarction: results from the OPTIMAAL study. European Heart Journal, 2009; 30(10): 1187-1194.

9. Schurtz G, Lamblin N, Bauters C, Goldstein P, Lemesle G. Copeptin in acute coronary syndrome and heart failure management: State of the art and future directions. Journal Archives of Cardiovascular Disease, 2015; 108(6-7): 398-407.

10. Elshafei A, Abdalla G, El-Motaal OA, Salman T. Copeptin: A neuroendocrine biomarker in acute myocardial infarction. Annual review \& research in Biology. SCIENCEDOMAIN International, 2013; 3(4): 1040-1054.

11. Nursalim A, Suryaatmadja M, Panggabean $M$. Potential clinical application of novel cardiac biomarkers for acute myocardial infarction. Acta Medical Indonesiana, 2013; 45(3): 240-250.

12. Kristyagita A, Siswanto BB. The role of copeptin as a novel cardiovascular biomarker. Medical Journal Indonesia, 2015; 24(1): 59-66.

13. Ay MO, Erenler AK, Dogan T, Yetim M. Diagnostic value of copeptin in acute myocardial infarction. European Review for Medical and Pharmacological Sciences, 2017; 21(7): 1576-1582.

14. Chung SR, Yang TH, Shin HC, Jin HY, Seo JS, et al. Initial total bilirubin and clinical outcome in patients with STsegment elevation myocardial infarction undergoing primary percutaneous coronary intervention with drug-eluting stents. Circulation Journal, 2016; 90: 1437-1445.

15. Cahill TJ, Kharbanda RK. Heart failure after myocardial infarctiom in the era of primary percutaneus coronary intervention: Mechanisms, incidence and identification of patients at risk. World Journal of Cardiology, 2017; 9(5): 407-415.

16. Gho JMIH, Postema PG, Conjin M, Bruinsma N, De Jong JSSG, et al. Heart failure following STEMI: A contemporary cohort study of incidence and prognostic factors. England. British Cardiovascular Society, 2017; 1-8.

17. Núňez J, Sanchis J, Núňez E. Effect of acute heart failure following discharge in patients with non-st elevation acute coronary syndrome on the subsequent risk of death or acute myocardial infarction. Rev Esp Cardiol, 2010; 63(9): 1035-1044.

18. Sulistijo SA, Novida $H$, Rudijanto A, Soewondo $P$, Suastika K, et al. Perhimpunan Dokter Spesialis Endokrinologi Indonesia. Konsensus Pengelolaan dan Pencegahan Diabetes Melitus tipe 2 di Indonesia. Ed I., Jakarta, PB Perkeni, 2015; 1-93.

19. Carillo S, Zhang Y, Fay R, Angioi M, Vincent J, et al. Heart failure with systolic dysfunction complicating acute myocardial infarction-differential outcomes but similar eplerenone efficacy by ST-segment or non-ST-segment elevation: A post hoc substudy of the EPHESUS trial. Archives of Cardiovascular Disease, 2014; 107(3): 149-157.

20. Ali WM, Zubaid M, El-Menyar A, Al Mahmeed W, AlLawati $\mathrm{J}$, et al. The prevalence and outcome of 
hypertension in patients with acute coronary syndrome in six Middle-Eastern countries. Blood Press Journal, 2010; 20(1): 20-26.

21. Feistritzer HJ, Klug G, Reinstadler SJ, Reindl M, Mayr A, et al. Novel biomarkers predicting cardiac function after acute myocardial infarction. British Medical Bulletin, 2016; 119(1): 63-74.

22. Ma QQ, Fan XD, Hao YY, Ma F. Short- and long-term prognostic value of hyponatremia in patients with acute coronary syndrome: a systematic review and meta analysis. PLOS ONE Journal, 2018; 13(3): 1-16.

23. O'Malley RG, Bonaca MP, Scirica BM, Murphy SA, Jarolim P, et al. Prognostic performance of multiple biomarkers in patients with non-st elevation acute coronary syndrome: Analysis from MERLIN-TIMI 36. Journal of the American College of Cardiology, 2014; 63(16): 1-19.

24. Rencher AC, Stoddard L, McNaughton CB, Williams JD, Tolland $M$, et al. Methods of multivariate analysis. Canada, John Wiley \& Sons, Inc. Publication, 2002; 2: 1-4, 43-81, 82-111. 